\title{
PENGARUH EKSTRAK ETANOL DAUN KELOR (Moringa oleifera Lam.) TERHADAP JUMLAH SEL MAST PADA MENCIT(Mus musculus) MODEL ENDOMETRIOSIS
}

\author{
Dina Novarita Kusuma Wardani ${ }^{1}$, Hendy Hendarto ${ }^{2}$, Widjiati $^{3}$ \\ ${ }^{1}$ Mahasiswa Ilmu Kesehatan Reproduksi Jenjang Magister, Fakultas Kedokteran \\ Universitas Airlangga Surabaya \\ ${ }^{2}$ Departemen Obstetri dan Ginekologi, Fakultas Kedokteran, Universitas Airlangga, \\ RSUD Dr. Soetomo \\ ${ }^{3}$ Departemen Embriologi Veteriner, Fakultas Kedokteran Hewan, Universitas Airlangga \\ e-mail : dinanovarita@gmail.com
}

\begin{abstract}
ABSTRAK
Sel mast memainkan peran penting dalam respon imun bawaan dan secara signifikan meningkat pada endometriosis. Protease yang disekresi oleh sel mast memainkan peran penting dalam fibrogenesis. CRH dan akumulasi estrogen dapat mengaktifkan sel mast untuk melepaskan tryptase, mengaktifkan PAR-2, yang menyebabkan peningkatan sekresi VEGF, IL-8, dan IL-6 dan proliferasi jaringan ektopik. Daun kelor mengandung 46 antioksidan dan 36 antiinflamasi. Tujuan dari penelitian ini adalah untuk membuktikan pengaruh daun kelor terhadap penurunan jumlah sel mast pada mencit (Mus musculus) model endometriosis. Jenis penelitian ini adalah eksperimental laboratoris. Pembuatan model endometriosis dengan diinduksi oleh siklosporin A, jaringan endometrium, dan etinil estradiol dan dilakukan pada 24 ekor mencit betina umur 2-3 bulan dengan berat 20-30 gram. Subjek penelitian dibagi menjadi 2 kelompok yaitu kontrol dan perlakuan. Kedua kelompok menjadi model endometriosis pada hari ke-14. Selanjutnya pada hari ke-15, kelompok kontrol diberi NaCMC 0,5\%, sedangkan kelompok perlakuan diberikan terapi ekstrak etanol daun kelor dengan dosis 0,35 $\mathrm{mg} / \mathrm{g}$ BB/ hari. Hari ke-29 mencit diterminasi dengan dislokasio os cervikalis dan melakuakn pemeriksaan jumlah sel mast dengan pewarnaan Hematoxillin Eosin. Hasil penelitian menunjukkan rerata jumlah sel mast pada kelompok kontrol adalah $8.13 \pm 2.97$ kelompok perlakuan adalah $1.90 \pm 1.88$. Pada uji Mann Whitney didapatkan nilai $p=$ 0,00. Kesimpulan dari penelitian ini adalah pemberian ekstrak etanol daun kelor (Moringa oleifera Lam.) terbukti dapat menurunkan jumlah sel mast pada mencit (Mus musculus) model endometriosis.
\end{abstract}

Kata Kunci : sel mast, endometriosis, daun kelor, mencit 


\begin{abstract}
Mast cells play an important role in the innate immune response and they are significantly elevated in endometriosis. Proteases secreted by mast cells play an important role in fibrogenesis. CRH and estrogen accumulation can activate mast cells to release tryptase, activating PAR-2, which causes increased secretion of VEGF, IL-8, and IL-6 and ectopic tissue proliferation. Moringa leaves contain 46 antioxidants and 36 anti-inflammatory. This research aimed to demonstrate the effect of ethanolic Moringa oleifera leaf extract on mast cell count in endometriosis mice model. This was an animal laboratory experimental study. Endometriosis was induced by administration of cyclosporine A, human endometrium tissue and ethynil estradiol in 24 female mice which 2-3 month ages with 20-30 g average of body weight were used. Study subject was divided into 2 groups consisting of control group and treatment group. Both groups became models of endometriosis on day 14. Then on the 15th day, positive control group is given solution $\mathrm{Na}-\mathrm{CMC} 0,5 \%$, while treatment group given dose $0,35 \mathrm{mg} / \mathrm{g}$ $B W / d a y$. On the 29th day termination with dislocatio os cervicalis and then take the peritoneal tissue. the number of mast cells was examination with Hematoxillin Eosin staining. The results showed the average number of mast cells in the control group was $8.13 \pm 2.97$ and the treatment group was $1.90 \pm 1.88$. In Mann Whitney test obtained $p$ value $=0.00$. The conclusion of this research is giving the Moringa leaf ethanolic extract (Moringa oleifera Lam.) proven to decrease the number of mast cells in endometriosis mice model.
\end{abstract}

Keywords : mast cells, endometriosis, moringa leaf, mice 


\section{PENDAHULUAN}

Endometriosis didefinisikan sebagai adanya jaringan seperti endometrium di luar rahim, yang menginduksi reaksi inflamasi kronis (Hendarto et al., 2014). Endometriosis merupakan suatu kelainan ginekologik yang sering diderita perempuan usia reproduksi. Struktur panggul paling sering terkena, tapi endometriosis bisa melibatkan organ ekstrauterin yang jauh seperti paru-paru (Azizad dan Clarke, 2014). Diperkirakan 5-10\% dari populasi wanita secara umum dipengaruhi oleh endometriosis, dengan prevalensi yang lebih tinggi (20-30\%) di kalangan wanita infertil, sehingga mendukung hubungan kausal antara endometriosis dan infertilitas (Giudice et al., 2010). Penelitian lain menunjukkan $25 \%$ sampai $50 \%$ wanita inferil menderita endometriosis dan $30 \%$ sampai $50 \%$ dari wanita dengan endometriosis itu infertil (ASRM, 2012).

Proses angiogenesis atau pembentukan pembuluh darah baru mempunyai pengaruh besar dalam perkembangan progresivitas lesi endometriosis yang ditandai dengan peningkatan luas implan lesi endometriosis. Sekresi VEGF oleh aktivasi sel mast pada jaringan endometriosis dapat dihambat dengan mencegah aktivasi Nuclear Factor KappaB (NF-кB). Penelitian yang dilakukan Zhang et al. (2015) membuktikan bahwa quercetin dapat menginduksi apoptosis sel kanker colon manusia melalui inhibisi NF- $\kappa B$. Kelor mengandung flavonoid, sedangkan kandungan flavonoid tertinggi pada kelor (Moringa oleifera Lam.) adalah Quercetin dan Kaempferol. Penelitian Nieman (2007) menunjukkan bahwa ekstrak air daun kelor memberikan aktivitas antiinflamasi secara invitro dengan mekanisme penghambatan NF$\kappa \mathrm{B}$.

NF- $\kappa \mathrm{B}$ dapat menyebabkan peningkatan sitokin proinflamasi, sedangkan sitokin proinflamasi juga berkontribusi terhadap pertumbuhan sel mast (Min et al., 2007). Sel mast berperan penting pada awal dan akhir fase inflamasi sebagai respon terhadap imunoglobulin E (Ig E) dalam pelepasan histamine, protease, prostaglandin, dan beberapa sitokin inflamasi (Galli et al., 2005). Berdasarkan penelitian Min et al. (2007) menunjukkan bahwa quercetin dapat menghambat ekspresi sitokin pro inflamasi pada sel mast. Quercetin melakukan block terhadap aktivasi p38 mitogen-activated protein kinase (MAPK) dan NF- $\kappa \mathrm{B}$, oleh karena itu sitokin pro inflamasi melemah (Min et al.,2007).

Saat ini penelitian dan uji klinis tentang fungsi kelor sebagai obat mulai berkembang meskipun manfaat dan khasiatnya belum banyak diketahui oleh masyarakat. Penemuan terbaru adalah fungsi daun kelor sebagai farmakologis, yaitu antimikroba, antijamur, antihipertensi, antihiperglikemik, antitumor, antikanker, pro-implantasi (Toma dan Deyno, 2014). Belum banyak penelitian tentang efek penggunaan ektrak daun kelor terhadap kesehatan reproduksi wanita, sehingga penelitian ini bertujuan untuk Membuktikan pengaruh pemberian ekstrak etanol daun kelor (Moringa oleifera Lam.) terhadap penurunan jumlah sel mast pada mencit (Mus musculus) model endometriosis.

\section{MATERI DAN METODE}

Jenis penelitian yang digunakan adalah true experimental dengan menggunakan rancangan acak lengkap randomized post test only control group design. Populasi dalam penelitian ini 
adalah mencit (Mus musculus) galur Balb/c betina, dengan jumlah sampel yang digunakan sebanyak 24 ekor mencit yang dibagi menjadi 2 kelompok dan setiap kelompok memenuhi kriteria inklusi antara lain : berumur 2-3 bulan, sehat dan anatomi tampak normal, sudah pernah beranak 1 kali, bobot minimal 20-30 gram, serta belum pernah digunakan sebagai obyek penelitian sebelumnya.

Bahan yang digunakan untuk penelitian ini yaitu lesi pada jaringan peritoneum mencit model endometriosis, ekstrak etanol daun kelor yang didapatkan dari UPT Materia Medica Batu Malang, siklosporin A (sandimmun), ethynil estradiol, penicllin $200 \mathrm{IU} / \mathrm{ml}$, streptomisin 200 $\mu \mathrm{gr} / \mathrm{ml}$, water fluid injection, jaringan endometrium dari pasien post histerektomi dengan tumor pada uterus, $\mathrm{Na} \mathrm{CMC} 0,5 \%$, pewarnaan Hematoxylin Eosin, phosphate buffered saline (PBS), air PDAM untuk minum.

Pembuatan mencit model endometriosis diawali dengan melakukan aklimatisasi pada mencit selama 7 hari. Selanjutnya mencit dibagi menjadi 2 kelompok secara acak. Pembuatan model endometriosis dimulai dengan pemberian injeksi siklosporin A $10 \mathrm{mg} / \mathrm{kg} \quad \mathrm{BB}$ dan ditambah injeksi jaringan endometrium wanita dengan tumor jinak uterus secara membuta sebanyak $0,1 \mathrm{ml}$ selama 60 detik kemudian diinjeksi ethinyl estradiol $20.000 \mathrm{IU} 0,1 \mathrm{ml} / \mathrm{mencit} / \mathrm{hari}$ diberikan secara IM di femur pada hari 1 dan 5. Jaringan endometrium diambil dari bahan uterus tumor jinak, yang disimpan di PBS (phosphate buffered saline). Dilakukan washing $2 \mathrm{x}$ dengan alat sentrifugal dengan putaran 2500 rpm. Supernatan dibuang kemudian ditambahkan PBS, penicillin $200 \mathrm{IU} / \mathrm{ml}$ dan streptomisin $200 \mu \mathrm{gr} / \mathrm{ml}$. diambil dengan syringe $3 \mathrm{ml}$ jaringan basah endometrium. Pada hari ke-14 menjadi mencit model endometriosis.

Proses ekstraksi daun kelor dilakukan dengan metode maserasi dengan pelarut alkohol 96\%. Daun kelor diambil dari daerah yang sama, dan kebun yang sama, usia pohon sama yaitu usia 3 tahun, pada urutan ranting yang sama, dan di jam yang sama. Ekstrak etanol daun kelor (Moringa oleifera Lam.) yang digunakan merupakan hasil ekstraksi di Laboratorium Materia Medica, Batu, Malang. Ekstrak daun kelor dibuat dengan maserasi daun kelor segar selama 2 hari dengan suhu $30-35^{\circ} \mathrm{C}$ kemudian dihancurkan menggunakan blender, dan didapatkan serbuk daun kelor. Serbuk daun kelor sebanyak 100 $\mathrm{g}$ ditambahkan pelarut etanol $96 \%$ sebanyak $100 \mathrm{ml}$, dimasukkan ke dalam toples dan ditambahkan etanol 96\% lagi sebanyak 1 L, kemudian ditutup dan dibiarkan selama 48 jam terlindung dari sinar matahari. Campuran itu disaring sehingga didapat maserat. Ampas dimaserasi dengan etanol 96\% menggunakan prosedur yang sama. Maserasi dilakukan sampai didapat maserat yang jernih dengan shaker digital kecepatan $50 \mathrm{rpm}$. Hasil ekstrak cair diuapkan dengan rotary evaporator selama 2 jam (Husin, 2017).

Perhitungan dosis ekstrak etanol daun kelor yang akan diberikan ke mencit berdasarkan penelitian sebelumnya pada tikus yaitu $250 \mathrm{mg} / \mathrm{kg}$ BB yang dikonversi berdasarkan tabel konversi Lauren (2008). Dosis estrak etanol daun kelor setelah dihitung dan dikonversi maka didapatkan dosis sebesar $0,35 \mathrm{mg} / \mathrm{g}$ BB. Pemberian terapi untuk kelompok perlakuan diberikan secara peroral menggunakan sonde lambung dan sebelumnya disuspensi dengan menggunakan larutan $\mathrm{Na} \mathrm{CMC}$ $0,5 \%$. Pemberian $\mathrm{Na} \mathrm{CMC}$ dapat membantu ekstrak etanol daun kelor 
untuk larut dengan air. pemberian ekstrak etanol kelor selama 14 hari. Setelah itu mengorbankan mencit dengan cara dislokasi os cervikalis dan seketika darah akan berhenti mengalir. Mencit yang telah mati ditandai dengan : mata redup, reflek pupil negatif, dan denyut jantung negatif.

Penelitian dilakukan pada bulan Maret 2018 sampai Mei 2018 di kandang hewan coba dan Laboratorium Patologi Veteriner Fakultas Kedokteran Hewan Universitas Airlangga.

\section{HASIL DAN DISKUSI} Hasil

Pemeriksaan sel mast menggunakan metode pewarnaan hematoxylin eosin. Data jumlah sel mast diperoleh dari data skoring menurut Klopfleisch (2013). Skor jumlah sel mast diperoleh dengan cara menghitung sel mast pada 5 lapang pandang dengan menggunakan pembesaran 400x, kemudian dijumlah dan dikelompokkan menurut skor Klopfleisch. Pemeriksaan jumlah sel mast menggunakan mikroskop cahaya merk nikon H600L dan disambungkan dengan kamera digital DS Fi2 300 megapixel dan software pengolahan gambar Nikon Image System.

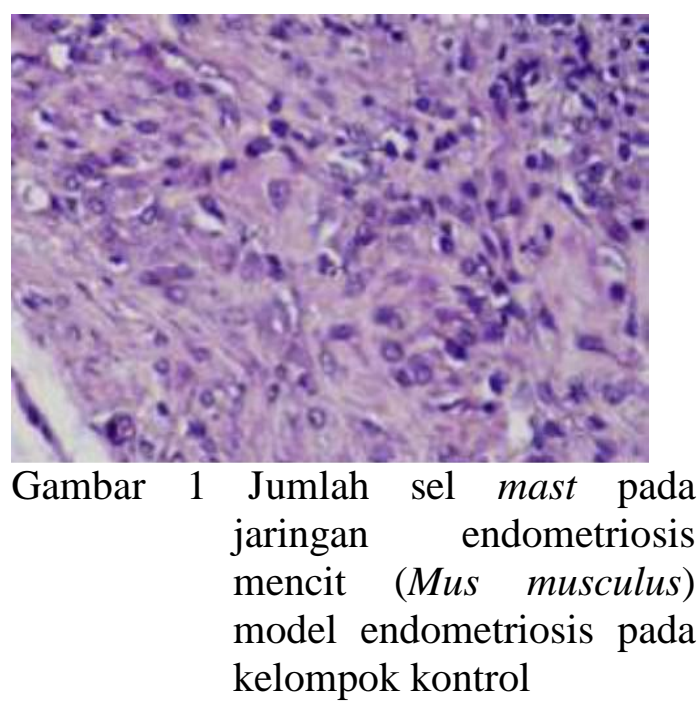

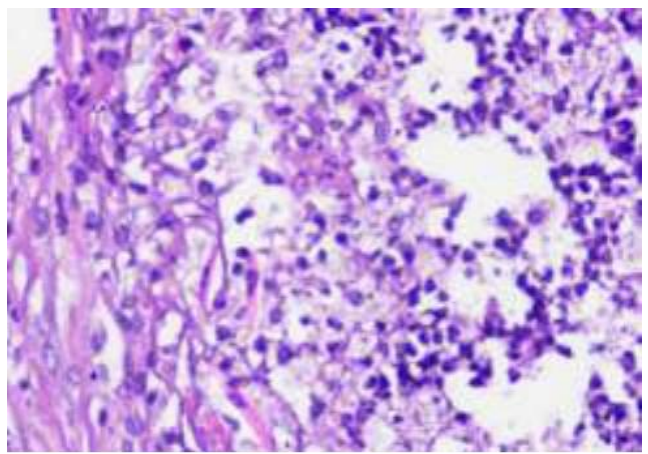

Gambar 2 Jumlah sel mast pada jaringan endometriosis mencit (Mus musculus) model endometriosis pada kelompok yang diberikan ekstrak etanol daun kelor

Tabel 1. Rerata dan simpangan baku jumlah sel mast

\begin{tabular}{llc}
\hline & Kelompok & $\begin{array}{c}\text { Jumlah sel } \\
\text { mast } \\
\text { Rerata } \pm \text { SD }\end{array}$ \\
\hline $\mathrm{X} 1$ & Kontrol & $8.13 \pm 2.97$ \\
\hline $\mathrm{X} 2$ & Perlakuan & $1.90 \pm 1.88$ \\
\hline
\end{tabular}

Tabel 1 menunjukkan rerata dan simpangan baku jumlah sel mast pada mencit (Mus musculus) model endometriosis antara kelompok kontrol dengan kelompok yang mendapat terapi ekstrak daun kelor (Moringa oleifera Lam.). Tabel distribusi frekuensi tersebut menunjukkan adanya penurunan jumlah sel mast pada kelompok perlakuan.

Analisis normalitas distribusi data menggunakan uji Shapiro wilk karena sampel dalam penelitian berjumlah kurang dari 50. Distribusi data normal apabila nilai $\mathrm{p}>0,05$. Berdasarkan hasil uji normalitas menunjukkan bahwa jumlah sel mast pada jaringan endometriosis mempunyai distribusi data tidak normal 
dengan nilai $\mathrm{p}=0,000$. Selanjutnya dilakukan uji homogenitas varian dengan menggunakan uji Lavene dan didapatkan nilai signifikansi kurang dari 0,05 sehingga asumsi homogen tidak terpenuhi. Data variabel jumlah sel mast setelah uji normalitas dan homogenitas selanjutnya dianalisis dengan menggunakan uji Mann Whitney untuk membandingkan nilai dua kelompok. Hasil uji Mann Whitney didapatkan perbedaan bermakna $(\mathrm{p}<$ $0,05)$ antara kelompok kontrol dengan kelompok perlakuan dengan nilai $\mathrm{p}=$ 0.000. Sehingga kesimpulan yang dapat diambil adalah terdapat perbedaan jumlah sel mast yang signifikan antara kelompok kontrol dan kelompok perlakuan.

\section{Diskusi dan pembahasan}

Sel mast merupakan sel penting dari sistem imun dan berasal dari hematopoietic lineage atau myeloid lineage. Sel mast berasal dari sel progenitor pluripotent dari bone marrow, dan matur dibawah pengaruh c-kit ligand dan stem cell factor. Sel mast dapat ditemukan di sel mukosa dan epitel pada seluruh tubuh (Krystel et al., 2016). Sel mast secara signifikan meningkat pada endometriosis. Protease yang disekresi oleh sel mast memainkan peran penting dalam fibrogenesis (Kempuraj et al., 2004). sel mast akan mengeluarkan enzym, seperti tryptase yang akan menstimulasi protease-activated receptor (PAR-2).

Penelitian yang dilakukan oleh Kempuraj et al. (2004) menunjukkan peningkatan jumlah sel mast pada pasien endometriosis dibandingkan dengan pasien-pasien tanpa endometriosis atau sebagai kontrol $(17.6 \pm 9.4$ sel mast $/ \mathrm{mm})$, cara mendeteksi peningkatan sel mast yaitu dengan mendeteksi peningkatan enzim triptase yang dihasilkan oleh sel mast yang mengindikasikan adanya reaksi alergi yang mendasari terjadinya reaksi peradangan pada endometriosis.

Penelitian ini menggunakan mencit betina sebagai hewan coba model endometriosis karena memiliki anatomi yang homolog dengan manusia. Pembuatan model hewan coba endometriosis membutuhkan waktu 14 hari dan selanjutnya salah satu kelompok diberikan terapi ekstrak etanol daun kelor dengan dosis 0,35 $\mathrm{mg} / \mathrm{g} \mathrm{BB} /$ hari selama 14 hari. Ekstrak etanol daun kelor mengandung salah satu senyawa anti-inflamasi yaitu quercetin yang diduga dapat menurunkan aktivitas sel mast melalui jalur NFkB. Penelitian yang dilakukan oleh Masyhur dkk. (2011) menunjukkan bahwa quercetin dapat menurunkan ekspresi protein proinflamasi penyebab aterosklerosis melalui penghambatan aktivasi NFkB.

Mencit dikorbankan pada hari ke-29 dan melakukan pemeriksaan jumlah sel mast menggunakan metode histologi dengan pewarnaan hematoxylin eosin. Berdasarkan hasil analisa statistik Mann Whitney menunjukkan perbedaan bermakna dan terdapat penurunan jumlah sel mast pada kelompok yang diberikan terapi ekstrak etanol daun kelor dibandingkan kelompok kontrol dengan nilai $\mathrm{p}<0,05$.

Flavonoid memiliki kandungan fitokimia yang berfungsi sebagai antioksidan dan antiinflamasi terhadap sel dengan stres oksidatif. Mekanisme antiinflamasi pada flavonoid yaitu dengan menurunkan stimulus inflamasi sehingga IKK kompleks yang terdiri dari IKK $\alpha$, IKK $\beta$, dan IKK $\gamma$ tidak melepaskan salah satu komponennya yaitu IKK $\alpha$. Tidak lepasnya IKK $\alpha$ dari struktur IKK kompleks mengakibatkan menurunyya fosforilasi IKK $\alpha$ menjadi IkB. Adanya penurunan fosforilasi IKK $\alpha$ menyebabkan IkB tidak 
mengalami degradasi proteosomal dan menurunnya aktivasi NFkB untuk melakukan transkripsi di nukleus (Yilmaz et al., 2011).

\section{SIMPULAN DAN SARAN}

Berdasarkan hasil penelitian dan pengolahan data statistik maka disimpulkan bahwa Pemberian ekstrak etanol daun kelor (Moringa oleifera Lam.) dapat menurunkan jumlah sel mast pada mencit (Mus musculus) model endometriosis.

Berdasarkan penelitian yang telah dilakukan maka dapat disarankan bahwa perlu dilakukan penelitian lebih lanjut tentang tingkat fertilitas mencit setelah diberikan terapi ekstrak etanol daun kelor (Moringa oleifera Lam.).

\section{DAFTAR PUSTAKA}

Azizad, P. and Clarke, D. 2014. 'Thoracic endometriosis syndrome: case report and review of the literature'. Permanente J. 18:61 - 65.

Giudice, L. C. 2010. 'Endometriosis'. N Engl J Med. 362:2389-2398.

Giudice, L. C., Swiersz, LM., Burney, RO. 2010. 'Endometriosis. In: Jameson JL, De Groot LJ (eds). Endocrinology'. New York: Elsevier, , 2356-2370.

Healy, D.L., Rogers, P.A., Hii, L., Wingfield, M. 1998. 'Angiogenesis: a new theory for endometriosis'. Hum Reprod Update. 4(5):736-40.

Hendarto, H. 2012. 'Pathomechanism of Infertility in Endometriosis'. In Endometriosis basic concept and current research trends. Intech : 343-353.
Hendarto, H. 2015. 'Endometriosis : dari aspek teori sampai penanganan klinis'. Surabaya : Airlangga University Press (AUP)

Nieman, D. 2007. 'Quercetin's Influence on ExerciseInduced Changes in Plasma Cytokines and Muscle and Leukocyte Cytokine mRNA'. Journal of Applied Pysiology. 103(5):1728-1735.

Zhang, X., Zhang, S., Yin, Q., and Zhang, J. 2015 . 'Quercetin induces human colon cancer cells apoptosis by inhibiting the nuclear factor-kappa B Pathway'. Pharmacognozy M. 11(42): 404-409.

Galli, SJ., Kalesnikoff, J., Grimbaldeston, MA., Piliponsky, AM., Williams, CM., and Tsai, M. 2005. 'Mast cells as "tunable" effector and immunoregulatory cells: recent advances'. Annu Rev Immunol. 23: 749-86.

Min, Y.D., Choi. C.H., Bark, H., Son, Y.H., Park, H.H., Lee, S., Park, J.W., Park,. E.K., Shin, H.I., and Kim, S.H. 2007. 'Quercetin inhibits expression of inflammatory cytokines through attenuation of NF-kB and p38 MAPK in HMC-1 human mast cell line'. Inflamm. res. 56(5):210-215.

Kempuraj, Castellani, M.L., Petrarca, C., Frydas, S., Conti, P., Theoharides, T.C. J., and Vecchiet. 2006. 'Inhibitory effect of quercetin on tryptase and interleukin- 6 release, and 
histidine decarboxylase

mRNA transcription by

human mast cell-1 cell line'.

Clin Exp Med. 6:150-156.

Kempuraj, D., Papadopoulou, N., Stanford, E.J., Chritodoulou, S., Madhappan, B., Sant, G.R., Solage, K., Adams, T., and Theoharides, T.C. 2004.

'Increased Number of

Activated Mast Cells in

Endometriosis Lesions

Positive for Corticotropin-

Releasing Hormone and

Urocortin'. American Journal

of Reproductive Immunology.

52: 267-275 